\title{
La "Poesía Gauchesca" como Fenómeno Literario
}

\section{LA SINGULARIDAD DEL FENÓMENO GAUCHESCO}

La llamada "poesía gauchesca" es un fenómeno excepcional, casi único en la historia de las literaturas hispánicas de América. ${ }^{1}$ No hay nada que equivalga, en los demás países americanos, a este géneto característico del Río de la Plata. La afirmación no es nueva, ni original: el hecho ha sido observado antes por muchos críticos e historiadores. Menos son los que han tratado de explicarlo.

Borges, entre otros, ha intentado una respuesta. ${ }^{2}$ La literatura gauchesca fue posible en el Río de la Plata por la proximidad y compenetración que había entre el campo y la ciudad; porque coexistían dos estilos vitales -el urbano y el pastoril- que, a pesar de sus diferencias, poseían elementos afines. La "poesía gauchesca" fue el resultado natural de la curiosidad y el interés que el espectáculo del campo, a la vez bárbaro y heroico, despertó en los escritores de la ciudad.

No cabe duda de que esa situación de contacto, y hasta de convivencia, del campo y la ciudad, fue una de las condiciones indispensables

1 Desde luego, en otras literaturas europeas y, especialmente, en las literaturas regionales de España, ha habido manifestaciones semejantes de poesía rústica, en lengua dialectal o en jerga vulgar. El fenómeno fue más notable en el siglo xIx, en parte al menos, por las mismas razones de historia literaria que explican la aparición de la "poesía gauchesca". Con todo, el desartollo de ésta tiene caracteres peculiares que no parecen haberse dado en otras partes. Conviene recordar, asimismo, que en otros países de Hispanoamérica, fuera del Río de la Plata, se ha intentado, también, imitar y emplear sistemáticamente la lengua dialectal y coloquial de los campesinos con fines literarios. Por ejemplo, algunos relatos de Tomás Carrasquilla y de Julio Posada. Pero son expresiones tardías que difieren, por su otigen y evolución, de la llamada "poesía gauchesca".

2 Jorge Luis Borges y Adolfo Bioy Casares, Poesía Gauchesca (MéxicoBuenos Aires, Fondo de Cultura Económica: 1955), vol. I, pág. VII. 
para que surgiese el fenómeno gauchesco. Pero no basta para explicarlo: condiciones parecidas se dieron y se dan aún en otros países de América.

El problema es más complejo de lo que parece. Porque la singularidad del fenómeno literario gauchesco no consiste sólo en el hecho de que se produjera únicamente en el Río de la Plata, sino en el modo mismo como se produjo dentro de la literatura rioplatense $y$, en particular, de la literatura argentina.

Consciente de ese otro aspecto del problema, Julio Caillet Bois ha planteado la cuestión en términos distintos. ${ }^{3}$ Caillet Bois reconoce, como Borges, la singularidad del fenómeno gauchesco, pero le extraña, sobre todo, el hecho de que la literatura argentina oficial no haya podido prescindir del género. Cree que el mérito literario no basta para explicar la enorme popularidad $y$, finalmente, el reconocimiento y consagración oficiales del género, hasta el punto de que Ricardo Rojas se sienta obligado a iniciar su historia de la literatura argentina con el estudio de "los gauchescos", a quienes considera "gérmenes originales de una fuerte y sana literatura nacional".

Caillet Bois se pregunta por qué motivos la literatura argentina no puede prescindir de lo gauchesco. Aparte las razones sentimentales e históricas, señala como una de las causas decisivas el hecho de que la literatura gauchesca tuvo, desde el principio, una significación cívica política y moral que no fue posible desechar. Pero, a su juicio, quizás la razón más importante sea el influjo de ciertas doctrinas estéticas del romanticismo. "Lo gauchesco, afirma, no hubiera ascendido de los planos infraliterarios y anónimos sin el concurso de la doctrina romántica que enaltecía todas las formas del arte popular". " Con el romanticismo quedaba abierto el camino para todas las expresiones de la literatura nativista, incluso el empleo de la jerga rústica de los paisanos. $\mathrm{Y}$, expresando con más claridad, lo que ya Martínez Estrada había entrevisto, 5 afirma que "los gauchescos" llevaron a sus últimas consecuencias el programa romántico de crear una literatura nacional. Sobre esta idea vuelve Caillet Bois al estudiar la figura de Hilario Ascasubi6 mostrando, con algún de-

3 Julio Caillet Bois, "Introducción a la poesía gauchesca; Hilario Ascasubi". En: Rafael Alberto Arrieta (ed.), Historia de la literatura argentina (Buenos Aires, Ediciones Peuser: 1959), vol. III, págs. 51-64.

4 Ibid., pág. 55.

5 Ezequiel Martínez Estrada, Muerte y transfiguración de Martin Fierro, 2a. ed. (México-Buenos Aires, Fondo de Cultura Económica: 1958), vol. I, págs. 278-279.

6 Gaillet Bois, op. cit., vol. III, págs. 65-89. 
talle, cómo dentro de la atmósfera del romanticismo la obra de Ascasubi alcanzó, a los ojos de los críticos cultos, un prestigio nuevo que contribuyó a enaltecer y justificar el género para siempre. "El triunfo de nuestra literatura gauchesca ante la crítica culta es, pues, un episodio del romanticismo..."7

El planteo de Caillet Bois se presta, sin duda, a una seria objeción. El hecho de que la "poesía gauchesca" sea un aspecto imprescindible de la literatura argentina puede justificarse sobradamente por la sola importancia estética de las dos obras más notables del género - Fausto y Martín Fierro- cuyo valor literario fue reconocido, desde un principio, por muchos críticos argentinos de la época y confirmado, antes de 1900, por Unamuno y Menéndez y Pelayo. Por otra parte, el planteo de Caillet Bois es demasiado circunscripto y sucinto. Se limita a considerar un solo aspecto y un único momento en el desarrollo del género gauchesco y no estudia en detalle el influjo que sobre él tuvo la doctrina romántica, tal como se la entendió y practicó en el Río de la Plata. Y, sin embargo, le cabe a Caillet Bois el enorme mérito de haber sido el primero en destacar la complicidad que le cupo al romanticismo en el proceso de exaltación y valoración críticas de la "poesía gauchesca" anterior a 1850.

Con todo, más interesante que la trascendencia y glorificación ulteriores del género, por la llamada crítica oficial, es la peculiaridad misma del fenómeno gauchesco cuando se considera el proceso de su origen, desarrollo y culminación dentro de la literatura rioplatense. En efecto ¿cómo se explica que lo que empezó siendo una forma bastarda de subliteratura, o a lo sumo de periodismo político, escrito en una lengua intencionalmente vulgar $-y$, a veces, en una jerga puramente inventada- llegara a convertirse, con el tiempo, en un modo de expresión legítima y respetable que entusiasmó, y llegó a tentar, a poetas cultos como Estanislao del Campo y Ricardo Gutiérrez, y culminó por último en Martín Fierro, la obra más original y quizás la más importante de todo el romanticismo hispánico? ¿Por qué no ocurrió otro tanto en los demás países de América donde también hubo manifestaciones parecidas de poesía seudopopular y de periodismo satírico en verso? ¿Por qué los escritores de otros países nunca intentaron utilizar esa materia semifolklórica para crear una literatura estéticamente más ambiciosa?

La respuesta obvia es que el fenómeno literario gauchesco respondió a circunstancias históricas, sociales $y$, sobre todo, ideológicas, que fueron

7 lbid., pág. 75 , 
peculiares del Río de la Plata y no se dieron del mismo modo, o con igual intensidad, en los otros países de América. Dentro de esas circunstancias, uno de los factores decisivos fue, como lo ha indicado Caillet Bois, el influjo del movimiento romántico, que tuvo, en Buenos Aires y Montevideo, rasgos fuertemente distintivos. Para comprender, sin embargo, la peculiaridad y complejidad del fenómeno gauchesco es indispensable examinarlo en su conjunto y discutir, en particular, el problema de su origen.

\section{LITERATURA GAUCHESCA Y CANTO PAYADORESCO}

$\mathrm{La}$ interpretación del fenómeno literario gauchesco ha constituido, hasta ahora, una especie de rompecabezas histórico al que nadie ha encontrado solución acertada, aunque irónicamente todas las piezas necesarias para resolverlo estaban a mano. El fracaso se ha debido, casi siempre, a que los críticos e historiadores de la literatura -en especial, los argentinos- en vez de buscar la figura verdadera, recomponiéndola con los hechos y datos que conocian, se dejaron llevar por prejuicios que halagaban emocionalmente su orgullo y vanidad patrióticos. Conviene recordar que el desarrollo de la "poesía gauchesca", desde el romanticismo, coincidió y se confundió con el proceso de creación del mito nacional del gaucho, sentido y concebido como símbolo y cifra de ciertas cualidades $y$ virtudes excelentes.

Pero, quizás, el motivo que con más frecuencia ha impedido juzgar adecuadamente el fenómeno gauchesco, ha sido el creer que la "poesía gauchesca" era una prolongación de la poesía cantada por los payadores, el reflejo de una tradición oral popular en la literatura escrita; o de otro modo, la elaboración literaria de una tradición oral más o menos remota. Son excepción los críticos que no han incurrido en este curioso espejismo. Aun aquellos que admiten que la "poesía gauchesca" no es obra de gauchos, sino obra escrita por poetas más o menos cultos de la ciudad - - lo que es evidente- caen a menudo en la ilusión de suponer que los orígenes de esta literatura deben buscarse en una tradición oral anterior $o$, por lo menos, en la obra improvisada oralmente por cantores anónimos populares.

En esa dirección algunos críticos han ido aún más lejos. Dando por supuesto que Martín Fierro es un poema de carácter épico - Unamuno y Menéndez y Pelayo fueron quizás los primeros en adelantar esta opi- 
nión- se ha querido equiparar a los payadores con los bardos de la Antigüedad o de la Edad Media, y el desarrollo de la "poesía gauchesca" con el de la épica primitiva. El mayor esfuerzo en ese sentido, lo encontramos en la construcción, tan falsa como admirable - o admirable por lo falsa-, que despliega Ricardo Rojas en su volumen sobre los gauchescos, motivo por el cual inicia, precisamente con ellos, la historia de la literatura argentina. De hecho Rojas, como todos los que antes y después de él coinciden en este punto de vista, no hacen sino reincidir en el mismo error de perspectiva en que, como veremos, incurrieron los románticos de mediados del siglo xix.

Parece absurdo tener que insistir una vez más en el hecho de que la "poesía gauchesca" no proviene del canto de los payadores. La circunstancia de que algunos de los personajes que figuran en los poemas gauchescos sean payadores e intervengan en contrapuntos, como ocurre en Martin Fierro, no basta para decidir que la poesía gauchesca sea una prolongación del canto payadoresco. Borges ha observado ya, que ni el lenguaje, ni los temas de la "poesía gauchesca" corresponden al lenguaje y los temas que, hasta donde podemos saberlo, empleaban los payadores: "... el rústico, en trance de versificar, procura no emplear voces rústicas. Tampoco busca temas cotidianos ni cultiva el color local". ${ }^{8}$

Y todavía podría agregarse que, con la notable excepción de Martín Fierro, generalmente los personajes de la "poesía gauchesca" anterior no cantan sino que hablan, conversan, "prosean"; y nunca compiten en contrapunto, sino que discuten temas de actualidad, o relatan episodios más o menos personales. Recuérdese, por ejemplo, que el famoso payador Santos Vega, en el poema de Ascasubi, sólo "canta", como por compromiso, unas décimas que no oímos y, el resto del tiempo, lo pasa contando la historia de los mellizos. ${ }^{9}$

Es necesario, pues, empezar por admitir que la "poesía gauchesca" fue, desde un comienzo, una creación literaria y que, incluso el gaucho, tal como lo conocemos a través de esa literatura, fue también un puro

8 Borges, op. cit., vol. I, pág. IX.

9 No cabe duda que José Hernández ha contribuido, más que ningún otro, a reforzar la ilusión del origen payadoresco de la "poesía gauchesca". No sólo porque todos sus personajes cantan y su héroe principal es un payador, sino porque en su obra hay más elementos tomados de la tradición oral hispánica o del folklore rioplatense. Hernández prestó mucha más atención al modo real de hablar y de cantar de los paisanos. Aunque pueda parecer paradójico, esa actitud revela, en él, una intención artística mucho más aguda que no tenían sus predecesores en el género. 
producto literario. Literatura escrita e impresa para ser leida, aunque existiese en los autores la esperanza de difundirla oralmente, como ocurrió, a través de la recitación y el canto.

Hasta donde sabemos, no cabe duda, tampoco, que el creador del género y del personaje gauchesco fue el uruguayo Bartolomé Hidalgo. Su creación, aunque modesta, era revolucionaria, como lo afirma Pedro Henríquez Ureña. ${ }^{10}$ Pero Hidalgo no surgió de la nada, por generación espontánea. Tuvo antecedentes estrictamente "literarios", directos e indirectos, que se remontan, por lo menos, hasta el último tercio del siglo xviII.

\section{Antecedentes literarios de Hidalgo}

Para comprender el sentido y la actitud literarias que informan la obra gauchesca de Hidalgo hay que considerarlo dentro de un amplio panorama de ideas e influencias que provienen del siglo xvur. Es sabido que a lo largo del siglo xviI, en todas las literaturas de Europa, se manifiesta un renovado interés por los tipos y formas de vida populares, que tiene su expresión más clara en el cuadro de costumbres, en el teatro y en la sátira. Ese interés por lo popular, que muchas veces se confundía con lo plebeyo y lo populachero, llevaba en muchos casos a recoger $y$ utilizar literariamente expresiones de la lengua vulgar y modismos locales o regionales, y en casos extremos, al franco remedo de la lengua hablada, especialmente para lograr efectos pintorescos o humorísticos. El hecho, desde luego, fue más notable en el teatro y en los versos satíricos.

Este fenómeno, a la vez social y literario - que se agudizó en Francia después de la Revolución, especialmente en el período jacobinotuvo, como sabemos, en la España del siglo xVII, y principios del XIX, una intensidad extraordinaria. Hubo en la España de entonces, al menos en ciertos sectores de la sociedad española, un verdadero culto de lo popular y de lo plebeyo, especialmente del mundo marginal de los majos y las manolas, como reacción castiza contra el amaneramiento de los currutacos y el afrancesamiento de los petimetres. La expresión literaria más conocida de esa tendencia costumbrista y popularista del siglo xvin español fueron, sin duda, los sainetes de Ramón de la Cruz por donde desfilaban, con sus características de lenguaje, majos, manolas, castañeras,

10 Pedro Henríquez Ureña, Las corrientes literarias en la América Hispanica (México-Buenos Aires, Fondo de Cultura Económica: 1949), pág. 115 
aguadores $y$ otros tipos populares del bajo Madrid, y donde se cantaban tonadillas y seguidillas.

Esta actitud, entre condescendiente y simpática, para con las costumbres y el habla de las clases populares se manifestó, también en la América española. No podía ser de otro modo, y en casi todos los países hubo expresiones literarias, o semi-literarias, de esa tendencia, en el teatro de género chico y en la poesía satírica. ${ }^{11}$ En el Río de la Plata, se han conservado dos ejemplos bien conocidos: el romance "Canta un guaso en estilo campestre los triunfos del Exmo. Señor Don Pedro Cevallos", escrito hacia 1778 por el canónigo Maziel, y el sainete anónimo en verso, El amor de la estanciera. Son dos composiciones satíricas, contra los portugueses, en las que encontramos el primer remedo de la lengua rústica campesina. En El amor de la estanciera se remeda, además, con intención humorística, el habla portuguesa. El portugués Marcos Figueira, del que en algún pasaje se dice que viene de España, no es sino una versión caricaturesca del clásico fanfarrón.

Estos son los antecedentes "litetarios" locales más lejanos que conocemos de lo que iba a ser más tarde, a partir de Hidalgo, la literatura gauchesca. Corresponden, en realidad, a una tendencia general de la literatura española e hispanoamericana de la época, aunque el criterio verista, de fidelidad a la realidad local, que inspiraba esta actitud literaria, exigiese que, en vez de ser majos y manolos, los personajes fueran campesinos - paisanos del Río de la Plata.

11 Conocidos ejemplos de teatro costumbrista en el Perú y en México, a fines del siglo xvir, son los entremeses de Fray Francisco del Castillo y de José Agustín de Castro, en los que, con mayor o menor acierto, los personajes populares utilizan expresiones vulgares y modismos regionales. Un poco anterior, y menos conocida, es la Loa del licenciado, obra anónima que se representó en la corte del Virrey en Lima, en 1744. En el prólogo de esta pieza se intenta la imitación fonética del habla de los indios (V. Rubén Vargas Ugarte, De nuestro antiguo teatro, Lima: 1943, págs. XXXVII-XL). También hubo imitación del habla de los negros. En este sentido, vale la pena recordar, aunque son bastante posteriores a la época que tratamos, las composiciones del uruguayo Francisco Acuña de Figueroa. La intención del autor, y el procedimiento utilizado, coinciden con los que animaban el periodismo gauchesco de su contemporáneo Ascasubi. Para el influjo de la lengua popular y vulgar en la sátira de la época colonial en México, véase: José Miranda y Pablo González Casanova (ed.), Sátira anónima del siglo xviII (México, Fondo de Cultura Económica: 1953). Conviene destacar además, que contemporáneamente con Hidalgo, Joaquín Fernández de Lizardi utilizó, especialmente en sus novelas y diálogos satíricos, el procedimiento de la imitación del habla popular y vulgar de México. 


\section{Canción POPUlar Y literatura política}

Al iniciarse el movimiento de independencia $-\mathrm{y}$, aún antes, durante el período de las invasiones inglesas- la literatura en todas sus formas y estilos se puso al servicio de la causa patriótica. Junto a las odas, cantos e himnos neoclásicos, surgió entonces, por necesidad, una subliteratura de propaganda política que no era sino una prolongación de la sátira anónima que en la época colonial solía asumir la forma del pasquín. Y, como había ocurrido antes en Francia, durante el período jacobino, y más directamente en España, durante la lucha con Napoleón, se utilizó en el Río de la Plata, al igual que en el resto de Hispanoamérica, el recurso del canto como un medio para divulgar ideas o noticias favorables a la causa de los revolucionarios entre las clases populares. Como es sabido, aparecieron así en las páginas de los periódicos porteños de la época, o impresas en hojas sueltas, composiciones breves para ser cantadas con acompañamiento de guitarra $u$ otros instrumentos populares. La melodía fue tomada de una de las danzas entonces más en boga, no sólo entre las gentes del campo, sino también entre los habitantes de la ciudad: el cielito.

Los innumerables cielitos políticos y patrióticos que se escribieron y circularon desde 1810, no eran todavía "poesía gauchesca", ni eran poesía popular, aunque fuesen anónimos y utilizasen expresiones o modismos vulgares y, muy a menudo, soeces. Eran obra de autores cultos. Lo único popular, en todo caso, eran los estribillos y alguna que otra copla intercalada, y la música con que se acompañaban. Si no hubiese otros testimonios, ${ }^{12}$ bastaría para fundar este juicio el examen cuidadoso de esos cielitos anónimos en los que, con mucha frecuencia, junto a expresiones e imágenes vulgares, de sabor más o menos campesino, encontramos conceptos y términos cultos, característicos de la poesía patriótica

12 Juan María Gutiérrez, en su estudio sobre la poesía de la revolución de Mayo, dice: "Las más veces es una misma la mano argentina que escribe la oda o compone el cielito; pero al dejar el vate la lira por la vihuela, acomoda y apropia la entonación, las ideas, el lenguaje mismo, al corto alcance de este humilde instrumento". Cf. Los poetas de la Revolución (Buenos Aires, Academia Argentina de Letras: 1941), pág. 11. Es cierto que Gutiérrez admite, además, la existencia de payadores y "bardos del desierto, cuyos nombres nos son desconocidos del todo", pero esta afirmación corresponde ya al proceso de idealización romántica que discutimos más adelante en este mismo trabajo. Por su parte, en una de sus letrillas satíricas, escrita hacia 1817, Domingo de Azcuénaga se burla del Dr. Ribera, que pasa el tiempo "haciendo cielitos". Cf. Juan de la C. Puig, Antologia de poetas argentinos (Buenos Aires, Martín Biedma e hijo: 1910), pág. 208. 
neoclásica. En un cielito de 1818 , descubierto por Ricardo Rojas, ${ }^{13}$ en que se celebra el triunfo de la batalla de Maipú se dice, por ejemplo:

"y publíquelo la fama
con su sonoro clarín."

Como vemos, la actitud literaria de Hidalgo, con ser revolucionaria y original, había sido precedida por una serie de intentos anteriores y provino, a mi juicio, no del canto anónimo de unos supuestos payadores, como Rojas y la mayoría de los críticos afirman, sino de una "tradición literaria" que, por modesta que fuese, era con todo literaria.14

Hidalgo compuso sus cielitos, o los que se le atribuyen, siguiendo una moda político-literaria del momento y escribió sus diálogos, inspirándose en la tradición del teatro costumbrista. Eso explica la forma dramática de estas últimas composiciones que se repetirá luego en todas las obras más importantes del género gauchesco. La indiscutible originalidad de Hidalgo consistió en haber creado el personaje del gaucho, bautizándolo con el nombre afortunado que desde entonces conservó. El término gaucbo no habia sido utilizado antes en literatura sino de modo ocasional. ${ }^{15}$ El mismo Hidalgo, en sus diálogos, parecía distinguir aun entre el gaucho Contreras y el capataz Chano, a quien nunca llama gaucho. De hecho, el término tenía en el uso corriente un sentido peyorativo y ha seguido teniéndolo hasta hoy en el campo argentino, al menos cuando se lo emplea como sustantivo. Por otra parte, no parece que el término haya sido de uso frecuente en la provincia de Buenos Aires, en la época de Hidalgo. Era un término nuevo, importado del Uruguay, con el cual se designaba generalmente a un tipo marginal de la sociedad, entre vaga-

13 Ricardo Rojas, Obras Completas (Buenos Aires, Editorial Losada: 1948), vol. I, págs. 311-313.

14 La obra más original de Hidalgo, como se ha señalado muchas veces, es la Relación, donde no sólo oímos y vemos actuar al gaucho Contreras, sino donde, además, el espectáculo de la ciudad y de la celebración del 25 de Mayo está visto desde el ángulo y la perspectiva del paisano. En rigor, es un cuadro de costumbres contemplado a través de los ojos forasteros del gaucho. Aunque no pueda pensarse en una influencia o vinculación directa, este artificio literario recuerda, sin embargo, al tantas veces empleado en las literaturas del siglo XviII: la visión perpleja que de la sociedad europea tenían ciertos imaginarios y exóticos viajeros; unas veces, sofisticados, como el persa de Montesquieu; y otras, irónicamente ingenuos, como el hurón de. Voltaire.

15 Aparece una sola vez en un cielito de 1819 que bien puede ser obra del propio Hidalgo. En El Detalle de la Acción de Maipú, sainete de 1818, se utiliza, también, una sola vez, y de un modo muy particular, el término "paisano-gaucho". 
bundo y delincuente. Las razones que tuviese Hidalgo para usarlo no podemos discutirlas ahora, pero creo que es válida la hipótesis que sugiere Emilio Coni en su estudio sobre el gaucho.16

\section{De Hidalgo a Ascasubi}

A Hidalgo corresponde no sólo el mérito de haber iniciado el género gauchesco, sino también el de haber fijado sus formas, mediante la utilización sistemática de la jerga campesina, el recurso dramático del diálogo y la introducción de temas que iban a repetirse luego en la literatura posterior. No es posible disminuir, por lo tanto, el carácter revolucionario de la creación de Hidalgo, aunque ella tenga antecedentes literarios y se explique por las peculiares circunstancias históricas en que surgió.

No cabe duda que la creación de Hidalgo tuvo gran difusión entre las clases populares de la ciudad y del campo, y que fue aceptada con complacencia por ciertos sectores cultos. De otro modo, no se explica la inclusión de dos de sus obras gauchescas en la primera colección poética La Lira argentina, publicada en 1824. En esta colección aparece, también, otra obra de Hidalgo de carácter muy distinto, El triunfo unipersonal, especie de drama o alegoria patriótica de evidente inspiración neoclásica. Es verdad que el compilador de La Lira argentina, Ramón Díaz, no era precisamente un escritor, ni tenía la intención de hacer una antología poética, sino la de teunir composiciones de valor histórico y patriótico. Es verdad, también, que en la Colección de poesías patrióticas de 1827, las composiciones gauchescas desaparecen y sólo se incluye el Triunfo unipersonal.

Pero cualquiera que haya sido la reacción de la mayoría de los escritores cultos de la época - y fue seguramente adversa - poco importó al futuro destino de la "poesía gauchesca". En otros países, o en otras circunstancias históricas, la obra de Hidalgo hubiese caído en el olvido. Pero en el Río de la Plata, conmovido en esos momentos por hondas luchas políticas, en perpetuo estado de guerra civil, la humilde creación de Hi-

16 Según Coni, el término gaucbo había sido usado por los españoles, durante el sitio de Montevideo, para calificar despectivamente al ejército patriota. Güemes y sus oficiales "recogieron el vocablo que se le habia lanzado como un insulto y le dieron popularidad y sentido elogiosos". Hidalgo participó en la lucha de Montevideo $y$, al parecer, también en las campañas del Norte. El vocablo debió tener, para él, un sentido de afirmación y desafío. Cf. Emilio Coni, El Gaucho: Argentina, Brasil, Uruguay (Buenos Aires, Editorial Sudamericana: 1945), págs. 219-220. 
dalgo no pasó desapercibida y su ejemplo tuvo continuadores. Lo decisivo no fue el valor estético, sino el hecho de que esta figura del gaucho, con su peculiar manera de expresarse, tenía un atractivo especial. El gaucho de Hidalgo no sólo aparecía en sus obras como un símbolo de lo popular criollo opuesto a lo español -y opuesto, en primer término, por su lenguaje- sino que servía, también, como en el Diálogo patriótico interesante y en la Relación, para oponer el hombre de poncho, al de "casaca y pantalón"; el hombre humilde de las clases populares, al "señorón" de la ciudad.

En este último aspecto el que sedujo, sin duda, por sus posibilidades y eficacia política, a Luis Pérez, editor desde 1830 de varios periódicos de propaganda rosista en que se empleaba, de preferencia, el estilo gauchesco y cuyas composiciones en verso se inspiraban evidentemente en la obra de Hidalgo.

Sabemos que, en respuesta a este tipo de periodismo popular rosista, Hilario Ascasubi inició su serie de periódicos unipersonales y folletos gauchescos, primero en Buenos Aires y, luego, en su destierro de Montevideo. La inspiración inicial de su obra provino, también, de Hidalgo.

Desde 1830 hasta 1850, con intermitencias, la actividad literaria de Ascasubi consistió en esta forma de periodismo político, escrito en verso gauchesco, en el que difícilmente podemos discernir ningún valor poético. Con pocas excepciones, esta obra periodística está por debajo del nivel de Hidalgo. Sin embargo, cuando después de caído Rosas, Ascasubi recogió esa ingente producción político-satírica, de carácter puramente circunstancial, en el volumen titulado Trovos de Paulino Lucero, publicado en Buenos Aires en 1853, la crítica le fue francamente favorable y en ciertos casos, exageradamente encomiástica. El hecho mismo de que hubiese podido publicar un libro de esta naturaleza, en un momento en que no era fácil imprimir libros, prueba que su obra contaba, de antemano, con un ambiente de simpatia.

La eficacia política de este periodismo gauchesco de Ascasubi, que había llegado y conmovido a sectores populares donde la prensa doctrinaria de los enemigos de Rosas no podía tener ningún efecto, no basta para explicar la acogida favorable de su obra en los círculos literarios cultos. Ella se debió en gran parte, como lo ha mostrado Caillet Bois, al influjo del romanticismo.

Fue precisamente en esos veinte años, entre 1830 y 1850 , cuando surgió y produjo sus mejores obras la primera generación de románticos argentinos. El movimiento, como sabemos, se inició en Buenos Aires bajo la 
égida de Esteban Echeverría. Con la emigración política argentina, su influencia irradió hacia los otros países y se hizo sentir, sobre todo, en Montevideo donde, desde 1832, residía Ascasubi. ¿Qué significación tiene la doctrina y la obra de los románticos para el destino futuro de la poesía gauchesca y, sobre todo, para su reconocimiento como una forma literaria legítimamente valiosa?

\section{DOCTRINA ROMÁNTICA Y LITERATURA NACIONAL}

Por lo pronto, el romanticismo argentino, desde sus comienzos, tuvo un fuerte sentido nacionalista. El primer punto de su programa era lograr la independencia intelectual y espiritual del país, no sólo respecto del clasicismo -eso hubiese reflejado sólo un punto de vista estrictamente estético- sino de la tradición colonial española y de todo lo español, en la medida en que representaba, para ellos, un pasado negativo y retrógrado.

Está demás recordar que el movimiento romántico argentino surgió desconectado del español, y hasta cierto punto lo precedió, y que se nutría primordialmente de ideas francesas, o conocidas a través de Francia.

Uno de los medios de afirmar la independencia intelectual y espiritual era crear una literatura y un arte nacionales que se inspirasen en la realidad del país, en la peculiaridad de la naturaleza y en las características originales de su sociedad. La originalidad era, sobre todo, lo que buscaban. "La poesía nacional, afirmaba Echeverria, es la expresión animada, el vivo reflejo de los hechos heroicos, de las costumbres, del espíritu, de lo que constituye la vida moral, misteriosa interior y exterior de un pueblo."17

De un modo aún más específico sostenía Sarmiento: "Si un destello de literatura nacional puede brillar momentáneamente en las nuevas sociedades americanas, es el que resultará de la descripción de las grandiosas escenas naturales $y$, sobre todo, de la lucha entre la civilización europea y la barbarie indígena, entre la inteligencia y la materia; lucha imponente en América, y que da lugar a escenas tan peculiares, tan características y tan fuera del círculo de ideas en que se ha educado el espíritu europeo, porque los resortes dramáticos se vuelven desconocidos

17 Esteban Echevertia, Obras Completas (Buenos Aires, Carlos Casavalle: 1874), vol. V, pág. 125 . 
fuera del país donde se toman, los usos sorprendentes, y originales los caracteres."18

En esta búsqueda apasionada de la originalidad nacional —que representaba mucho más que un mero afán de descubrir el color local y lo pintoresco- los románticos descubrieron emocionalmente, e introdujeron en la literatura, dos elementos que habrían de ser indispensables a la literatura gauchesca posterior: el vasto escenario desierto de la pampa, y el indio, en guerra con lo que ellos llamaban la civilización. Ese fue el mérito indiscutible de La cautiva de Echeverría que se impuso, entre los jóvenes románticos, por su significación doctrinaria más que por sus valores estéticos.

Al mismo tiempo que afirmaban el sentido nacionalista del arte y la literatura, los románticos redescubrieron y exaltaron el valor de lo popular, como forma espontánea, genuina, de lo nacional. De ahí el valor que concedieron a la canción como vehículo expresivo del alma nacional. Echeverría se lamentaba hacia 1836 de que en el Río de la Plata no exisuese, como en otros países, un cancionero popular vivo y, para suplir esta falta, concibió incluso el proyecto de crear él mismo un cancionero argentino.

A diferencia de Echeverria, Sarmiento reconocía en el Facundo, pocos años más tarde, la existencia de una poesía popular argentina: la "poesía candorosa y desaliñada del gaucho". 19

Dadas las tendencias iniciales, era inevitable que los románticos descubrieran la figura del gaucho y la explotaran literariamente. Pero lo que los románticos descubrieron no fue la misma figura, un poco deslucida, que hasta entonces habían reflejado los poetas gauchescos. Los románticos ennoblecieron la figura del gaucho. Con ellos se inició, en realidad, el proceso de idealización literaria del gaucho que iba a culminar, casi un siglo más tarde, en el Don Segundo Sombra de Ricardo Güiraldes.

En este proceso de idealización, le cupo un papel decisivo a Bartolomé Mitre, quien en sus Rimas, recreó y difundió la leyenda de Santos Vega, mitológico arquetipo del payador antiguo. El mismo Mitre -que fue un gran creador de mitos- contribuyó a exaltar románticamente la figura del soldado gaucho; es decir, el gaucho como símbolo del guerrero popular anónimo. Sarmiento, a su vez, presentó en su Facundo los tipos característicos del gaucho argentino: el baqueano, el rastreador, el pág. 47.

18 Domingo Faustino Sarmiento, Facundo (Buenos Aires, La Facultad: 1929), 19 Ibid., pág. 52. 
"gaucho malo" y, sobre todo, el cantor. Tipos idealizados que iban a reaparecer, de uno u otro modo, en la literatura gauchesca posterior a 1850 .

Como resultado de esta idealización romántica, el gaucho se convirtió en un tema literario prestigioso, lo que explica la serie de poemas cultos con tema gauchesco - pero que no eran gauchescos en su concepción- que se escribieron después de 1850, desde el Celiar del uruguayo Alejandro Magariños Cervantes, y el Lázaro de Ricardo Gutiérrez, hasta el Santos Vega de Rafael Obligado.

Pero hubo otros elementos en el romanticismo argentino que permiten entender mejor, y más de cerca, el proceso que nos ocupa: la dignificación literaria del propio género gauchesco.

\section{LA ACTITUD ANTE LA LENGUA}

En primer lugar, una nueva actitud ante la lengua. En su reacción contra España, la mayoría de los románticos reaccionó, también, contra el purismo y el principio de autoridad en materia de idioma. Una nueva nación, que aspiraba a tener una literatura propia y original, tenía que abrir nuevos cauces a la lengua recibida de España, enriqueciéndola con nuevos vocablos y modismos.

Ya Echevertía en el prólogo de La Cautiva justificaba el empleo de locuciones vulgares y voces americanas en nombre de la verdad poética. ${ }^{20}$ $Y$ en El Matadero fue aún más lejos, al reproducir con enérgica fidelidad el habla vulgar de los matarifes. Pero; como siempre, el más cxagerado, el que llevó a sus extremos teóricos esta nueva actitud - de desprecio de las normas y de exaltación de lo espontáneo y lo popular en la lengua- fue Sarmiento en su polémica de Chile en 1842. Llegó a decir: "La soberanía del pueblo tiene todo su valor y su predominio en el idioma; los gramáticos son como el senado conservador creado para resistir a los embates populares, para conservar la rutina y las tradiciones".21 Y agregaba: "los pueblos en masa y no las academias forman los idiomas". ${ }^{22}$

Es cierto que los románticos no llevaron esta doctrina hasta sus últimas consecuencias prácticas, pero crearon una atmósfera favorable a la

20 Echeverría, op. cit., vol. V, págs. 144-145.

21 Sarmiento, Obras (Santiago de Chile-Buenos Aires, Imprenta Gutemberg, 1885-1914), vol. I, pág. 209.

22 Ibíd., pág. 220. 
aceptación, no ya indulgente sino entusiasta, de la llamada "lengua gauchesca" como instrumento válido de expresión auténticamente literaria. Es verdad, también, que muchos de los viejos románticos, como Mitre, rechazaron siempre los extremos de verismo y de vulgaridad manifiestos en el habla gauchesca.

En 1854, aludiendo sin duda a la obra de Hidalgo y Ascasubi, Mitre declaraba: "Las costumbres primitivas y originales de la pampa han tenido entre nosotros muchos cantores, pero casi todos ellos se han limitado a copiarlas; en vez de poetizarlas poniendo en juego sus pasiones, modificadas por la vida del desierto, y sacando partido de sus tradiciones y aun de sus preocupaciones. Así es que, para hacer hablar a los gauchos, han aceptado todos los barbarismos, elevando al rango de poesía una jerga muy enérgica, muy pintoresca y muy graciosa, para los que conocen las costumbres de nuestros campesinos, pero que, por sí sola no constituye lo que propiamente puede llamarse poesía". 23 de un modo aún más terminante se expresaba en la carta que, en 1879, escribió a José Hernández, acusando recibo de su Martín Fierro. Pero, a pesar de estas reacciones individuales -un poco tardías-, los románticos contribuyeron con sus doctrinas a enaltecer, a los ojos de un importante sector de opinión, el valor literario de la jerga popular de los gauchescos.

Con el romanticismo se difundieron; ademăs, nuevas ideas acerca de los orígenes de la literatura $y$, en particular, de la poesía épica. Haciéndose eco de ideas muy difundidas en la crítica europea desde fines del siglo xvir, concebían la poesía primitiva como creación espontánea de los pueblos, u obra de bardos anónimos que, en una lengua inculta pero vigorosa, improvisaban cantos guerreros heroicos que habrian de constituir más tarde la materia de los grandes poemas épicos.

Consecuente con esta idealización, afirmaba Echeverria que hasta los indios nómades de la pampa "tienen sus cantos guerreros con que celebran las hazañas heroicas, perpetúan su memoria, y se infunden espiritu en los combates" ${ }^{24} \mathrm{Y}$ dando una nueva y significativa aplicación a la doctrina, Sarmiento comparaba al gaucho cantor con los bardos de la Edad Media, consideraba heroicos sus cantos, y sostenía que el gaucho cantor: "está haciendo candorosamente el mismo trabajo de crónica, costumbres, historia, biografía, que el bardo de la Edad Media". ${ }^{25}$ Y agre-

23 Cit. por Rojas, op. cit., vol. II, pág. 617 .

24 Op.cit. vol. V, pág. 110.

25 Satmiento, Facundo, pág. 62. 
gaba que, si no hubiese existido en el país una sociedad culta "con superior inteligencia de los acontecimientos", esas ingenuas rapsodias serían los documentos y datos en que tendría que apoyarse el historiador futuro. Mitre, por su parte, llamaba a Santos Vega "bardo inculto de la pampa".

Esta glorificación épica del payador y del cantor gaucho iba a ser transferida más tarde a los propios poetas gauchescos, empezando por Ascasubi. Sólo así se explica el curioso juicio que formula el historiador Vicente Fidel López en 1851 cuando dice: "los cuadros y las creaciones del señor Ascasubi serán sin disputa la fuente, los antecedentes homéricos de nuestra futura literatura, y en este concepto es inmenso el valor histórico a que creemos está reservado a ese nombre reducido hoy entre nosotros a un valor modesto tal vez". ${ }^{26}$

\section{ROMANTICISMO Y LITERATURA HUMANITARIA}

Hay, finalmente, otra razón que quizás explique mejor la aprobación y el entusiasmo con que algunos críticos recibieron la publicación, en 1853, del volumen de versos político-satíricos de Ascasubi. Y es la importancia que el romanticismo concedió al contenido ideológico y a la función social de la literatura.

No debemos olvidar que el romanticismo argentino surgió bajo la influencia del liberalismo democrático y humanitario, que se manifestó abiertamente en Francia después de la Revolución de 1830, y que preparó ideológicamente la Revolución de 1848. De acuerdo con la filosofía, a un mismo tiempo política y estética, de este romanticismo humanitario, existía una correspondencia estricta entre la sociedad y la literatura: la literatura era una expresión de la sociedad.

Alberdi lo decía claramente en 1841: "Tenemos que convenir que si nuestra poesía ha de ser la expresión de la sociedad que nace en América, y no de la sociedad de España que se retira, es necesario que, como nuestra sociedad, nuestra poesía sea nueva y se la deje pasar, por consiguiente, con todas las imperfecciones inherentes a toda cosa nueva: pretender que ella sea completa y que nuestra sociedad esté en germen, es desconocer la mutua dependencia, que todos reconocen hoy, de la literatura con la sociedad".2z

26 Cit. por Caillet Bois, op. cit., vol. III, pág. 89.

27 Juan Bautista Alberdi: Obras Selectas (Buenos Aires, La Facultad: 1920). yol. I, págs. 132-133, 
Al mismo tiempo que expresión de la sociedad, la poesía, la literatura debía ser un medio para transformarla. El poeta debía ser apóstol y profeta de la causa del progreso, la igualdad y la libertad democráticas. Hilario Ascasubi, con su modesto instrumento gauchesco, había prestado un inmenso servicio a esa gran causa humanitaria en la lucha contra la tiranía de Rosas. No es extraño que Valentín Alsina, amigo y protector político de Ascasubi, creyera con sentido realista que el género gauchesco, de tanta difusión en los estratos incultos de la sociedad, podía utilizarse para instruir a las masas y transmitir ideas que de otro modo no llegarian nunca a ellas. (Es lo que muchos años más tarde se propuso, o dijo proponerse, José Hernández en La Vuelta de Martín Fierro). Pero no es extraño, tampoco, que críticos más vehementes comparasen la obra de Ascasubi con la del francés Béranger. Refiriéndose al Paulino Lucero, decía Marcos Sastre en 1852: "como todas las composiciones de su autor, toma una dirección verdaderamente grande, y cual otro Béranguer, marcha tras la patria, la libertad y el pueblo, que es su Musa y su Parnaso". ${ }^{28}$ Un juicio parecido emitía en las columnas del Correo de Ultramar, en 1861, José María Torres Caicedo: "Por su robusta entonación en defensa de la patria tiene grande analogia con el amable Béranger, el bardo popular de Francia, tan amado por los hijos de las clases trabajadoras..." 29

La misma actitud humanitaria inspiró a la mayor parte de los críticos del periodo siguiente, entre 1860 y 1880 . Para Pedro Goyena, por ejemplo, la mejor composición de Estanislao Del Campo no era "Fausto", sino "Gobierno Gaucho", por su sentido político-social, y la compara con los cantos de Béranger. $Y$ si se revisan los juicios que mereció el Martín Fierro, a la gran mayoría de sus contemporáneos, se verá que, al mérito puramente literario, preferian su significación social y humanitaria: el haber servido para denunciar la injusticia que se cometía, o se había cometido, con el hombre humilde de la clase campesina.

\section{Romanticismo y "poesía gaUChesca"}

El influjo de las doctrinas románticas no sólo contribuyó a enaltecer el valor de la "poesía gauchesca" ante los ojos de muchos escritores y críticos cultos, sino que influyó directamente en la obra misma de los

28 V. Puig, op. cit., vol. VIII, pág. XXII.

29 Ibid., pág. XXI. 
gauchescos. No cabe duda que la amistad con los románticos y el contacto con sus ideas, provocaron en el propio Ascasubi un cambio de actitud respecto de su propia creación. A pesar de sus muchas protestas de humildad, Ascasubi pareció convencerse de la importancia de su obra y de las posibilidades del género gauchesco, limitado, hasta entonces, a su función de literatura o periodismo de combate. Sólo asi se comprende que, en 1850, concibiese el proyecto, mucho más ambicioso, de componer un gran poema gauchesco, del que llegó a escribir por entonces más de mil versos, y que constituyó el germen de su futuro Santos Vega. El título de esa primera versión incompleta era ya significativo: Los mellizos o rasgos dramáticos de la vida del gaucho en la campaña y praderas de la República Argentina. Indicaba la voluntad de trazar un vasto cuadro de la vida del gaucho, dentro de las ideas estéticas del romanticismo, como para poner a prueba las posibilidades artísticas del géneto. Ascasubi parecia tener plena conciencia de las limitaciones y de la inferioridad de la lengua que estaba obligado a emplear, pero la defendía en nombre de la autenticidad artística: por su fidelidad a la naturaleza o al modelo real que quería reproducir. Decía en el prólogo del poema, publicado en Montevideo en 1850: "El uso de este lenguaje, ajeno en muchas voces y modismos al idioma de la literatura española, era esencial y requerido para revelar los secretos y los hábitos de las campañas argentinas que el autor se ha propuesto sacar al conocimiento y examen de la crítica; porque en los pueblos, lo mismo que en los individuos, el estilo, el lenguaje, los modismos, son la parte más profunda, más homogénea, más explicativa de su ser". ${ }^{30}$

Al regresar a Buenos Aires, después de la caída de Rosas, Ascasubi volvió una vez más a cultivar el periodismo gauchesco, contra Urquiza y en defensa de la causa de Buenos Aires. Este periodo no agregó nada a su posible gloria literaria. El género gauchesco, sin embargo, estaba ya afianzado y reconocido: sólo era necesario, para que se consagrase como verdadera literatura, la aparición de escritores de mayor refinamiento artístico, como Estanislao del Campo; o de talento original, enérgica voluntad creadora y auténtica inspiración popular, como José Hernández.

Siguiendo direcciones distintas $y$, en cierto modo, divergentes, Del Campo y Hernández llevaron la "poesía gauchesca" a su verdadero plano estético y vinieton a justificar así, retrospectivamente, los humildes ensayos

30 Ibid., págs. XIX-XX. 
de Hidalgo y de Ascabusi. Pero no lo habrían logrado sin el estímuio de! romanticismo que creó el ambiente propicio e influyó, además, honda. mente en la obra de ambos.

ANíbal Sánchez Reulet

University of California,

Los Angeles 
